\title{
Onychomadéza - pozdní komplikace nemoci ruka, noha a ústa
}

\author{
prof. MUDr. Vladimír Mihál, CSc. \\ Dětská klinika LF UP a FN v Olomouci
}

Klíčová slova: nemoc ruka, noha a ústa; onychomadéza.

Key words: hand-foot and mouth disease; onychomadesis.
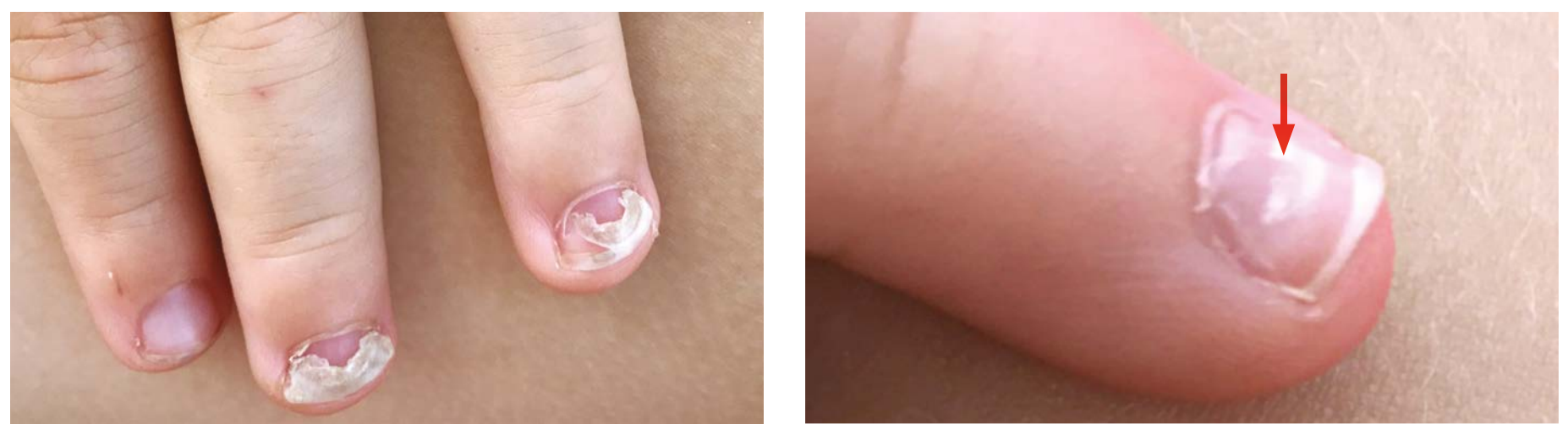

U dvou sourozenců (3 a 1,5 roku) pozorovala matka 6 týdnů po odeznění nemoci ruka, noha a ústa nápadné změny na nehtech rukou (deformity, bělavé obláčky, Beauovy linie). U mladšího chlapce došlo postupně ke kompletnímu odloučení všech deseti nehtů na rukách, u staršího sourozence pouze k částečné onychomadéze (obr. 1).

Nemoc ruka, noha a ústa je vysoce infekční virové onemocnění, které se $v$ jarních a podzimních měsících širíi v malých epidemiích. Typickým projevem je vezikulární exantém na rukou a nohou a prítomnost aftózních lézí v ústech. Vyskytuje se v dětském věku u dětí mladších než 5 let. Někdy, když jsou děti infikované, mohou být jejich rodiče bezpríznakovými nosiči s velmi mírným průběhem. Toto onemocnění má obvykle krátké trvání a benigní průběh. Enterovirus 71 a virus coxsackie A16 bývají jeho nejčastější prričinou. $\checkmark$ naprosté většině prípadů se nemoc ruka, noha

\section{LITERATURA}

1. Bernier V, Labraze C, Bury F, et al. Nail matrix arrest in the course of hand, foot and mouth disease. Eur J Pediatr 2001; 160: 649-651. a ústa projevuje jako nezávažné onemocnění s relativně nekomplikovaným průběhem a rychlým uzdravením.

Vztah mezi nemocí ruka, noha a ústa a onychomadézou byl popsán již před šestnácti lety V. Bernierem a C. Labrazeovou (1). Dnes je možné dohledat desítky prípadů této spojitosti (2). Onychomadéza je pozdní komplikace, kterou pozorujeme zpravidla čtyři až šest týdnů po počátku onemocnění. Je obvykle samolimitující a nevyžaduje žádnou léčbu. Rozsah deformit nehtů je široký, od leukonychie (bělavé obláčky), Beauových linií až k částečnému nebo kompletnímu odloučení nehtů na ruce nebo noze. Krátkodobé zpomalení tvorby nehtu vede k Beauovým liniím, zatímco dlouhotrvající zástava zapríčiňuje obvykle oddělení nebo dokonce shození nehtů.

Beauova linie je horizontální (transverzální) důlek v nehtové ploténce (označené šipkou na obr. 2), který probíhá paralelně s poloměsíčitou skvrnou bělavé barvy (lunula) v dolní části nehtové plotýnky. Joseph Honoré Simone Beau ji u pacienta s břišním tyfem popsal již v roce 1846.

Patogenní mechanismus vzniku onychomadézy u některých dětí po odeznění nemoci ruka, noha a ústa je stále nejasný. Uvažuje se o možném neuropatogenním účinku EV71, přimém dystrofizujícím účinku replikujícího se viru v nehtové ploténce, ale i rozšiření infekce z okolité, virem infikované kưže.

Nicméně onychomadéza per se nemá charakter infekce, ale může být pouze následkem infekčního procesu, často lokalizovaného velmi blízko nehtového lưžka. Dalším vysvětlením je, že nemoc ruka, noha a ústa může mít mnohem těžší dopad na celkový stav u mladších dětí, může vést až k pozastavení růstu nehtů, což se až po několika týdnech projeví onychomadézou.

2. Hardin J, Haber RM. Onychomadesis: literature review. $\mathrm{Br}$ J Dermatol 2015; 172: 592-596. 